\title{
鉄筋コンクリート造柱部材のせん断非線形性状評価手法の実験的検証 EXPERIMENTAL VERIFICATION FOR EVALUATION METHOD OF NONLINEAR BEHAVIOR OF SHEAR DEFORMATION FOR REINFORCED CONCRETE COLUMNS
}

\author{
杉本訓祥* \\ Kuniyoshi SUGIMOTO
}

\begin{abstract}
An evaluation method for the earthquake resistant performance of reinforced concrete columns and beams is developed for the performance based design. Six RC column specimens were tested to verify the proposed method. Main features of the proposed method to be verified are 1) transverse and longitudinal stiffness and 2) separation into five regions along the length. Main parameters of the test specimens are the existence of sub tie for transverse reinforcement, the failure mode (i.e. flexure or shear) and the size of specimens. The calculations by the proposed method show good accordance with both the experimental and FEM analytical results. Furthermore calculation method for shear crack width is developed and compared with the experimental results. Calculated crack widths correspond well with the measured ones.
\end{abstract}

Keywords: Restoring Force Characteristic, Shear Deformation, Shear Crack Width, FEM Analysis 復元力特性, せん断変形，せん断ひびわれ幅，FEM 解析

1. はじめに

建築物の構造設計が仕様規定型から性能評価型 ${ }^{11}$ に移行するにあ たり，構成部材の復元力特性の把握と損傷度の評価が求められ，鉄 筋コンクリート造（以下 RC 造）部材の損傷度を表す指標としてひび われ性状について着目されつつある. 地震により被災した建物の損 傷程度を残留ひびわれ幅により定義することは一般的に行われてい る ${ }^{2}$ が，設計段階では，損傷度合いの評価方法として，部材の変形量 や塑性率などを用いることが一般的である．従って，例えば塑性率 2 を設計クライテリアとした場合でも，部材を構成する要素によっ ては，同じ地震を受けた場合の損傷度が異なる可能性をはらんでい る.部材の復元力特性評価と同様に、ひびわれ幅を指標とした損傷 度の評価が可能になれば，想定した地震動に対する応答に対し，塑 性率だけでなく，ひびわれ幅を指標とした損傷度を設計クライテリ アとすることが可能になる．このことは，同じ塑性率 2 をライテ リアとして設計された部材でも，その他の要因を変えることで，損 傷度の小さな（被害の小さい）部材を設計することが可能になるこ とを示唆している，曲げ及びせん断ひびわれは，それぞれ曲げ及び せん断変形成分に相関していることが指摘されている ${ }^{3), 4)}$. 一方，せ ん断変形は弾性と仮定することが一般的であるが，通常曲げ降伏を 許容しない柱部材では，設計用応力に対して耐力余裕度を確保する 設計を行うため，曲げ耐力に対するせん断耐力余裕度を必ずしも十 分に確保しないことから，せん断に関する復元力特性が非線形とな り，せん断変形成分が卓越する場合もあると予想される．以上のよ うな背景から，せん断非線形性状を把握するために， RC 造柱部材の 静的実験を実施した。

一方，筆者は，せん断成分の復元力特性評価法に関する検討を進
めており，既報 5)で簡略的な評価手法を提案し，その詳細を報告した。 既報では，簡略的な評価手法について，荷重-変形関倸のみに着目し て既往実験結果と比較検討しており，詳細な検討が不十分であると 考えられる. そこで, 本論文では, 特に復元力特性評価の過程にお いて導出されるせん断变形角と相関する部材軸方向および部材軸直 交方向の歪度の進展状況に着目して静的害験結果との比較検証を行 う。また，本提案手法は建物の架構全体を対象とした骨組解析に有 用であるが, 架構の一部分などの詳細解析手法としてはFEM 解析が 有用である.FEM 解析の精度は向上してきており, パラメトリック スタディの有用なツールになると考えられる，そこで，簡略的な評 価手法と同様に実験結果を模擬できることを検証する目的で, FEM 解析も併せて実施した，本論文では，せん断非線形性状把握を目的 として実施した RC 造柱部材の静的実験を対象とし, 簡略的な評価手 法による計算と FEMによる詳細解析を行い, 計算による評価精度お よび解析精度を詳細に検証した結果を述べる，実際の地震時の部材 の挙動は, 繰り返しによる劣化やひびわれ幅の拡幅なども想定され るため, 履歴特性の評価も重要であり，履歴ルールと包絡線の組み 合わせにより部材の挙動を表現することが一般に行われる，履歴ル 一ルについては曲げ型の履歴モデル の), せん断型の原点指向型履歴モ デルの，耐力劣化を表現したモデル》など, 数多く提案されているが， せん断変形成分と曲げ変形成分を区別した包絡線については多くは 言及されていない．既報の簡略的な評価手法は, 復元力特性のうち 包絡線（スケルトンカーブ）に着目したものであり，本論文では， その評価精度の検証を基本とする。

さらに, 簡略的な評価手法を拡張し, 包絡線上の各変位時のせん 断ひびわれ幅の算定法を考案し，実験結果と比較する。 

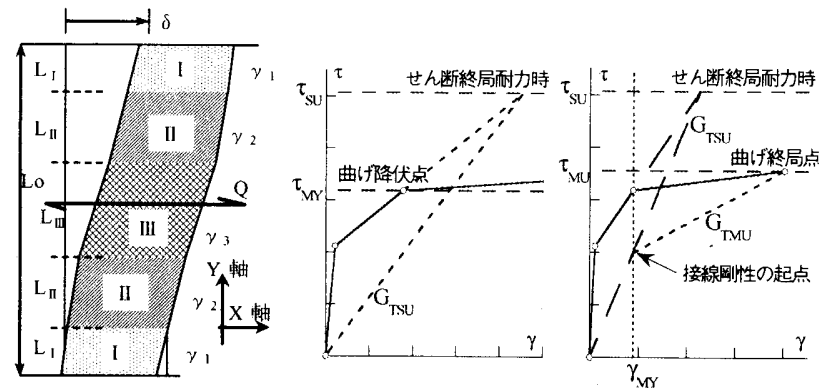

図-1 部材の分割

図-2 曲げ降伏先行型部材のスケルトンカーブ

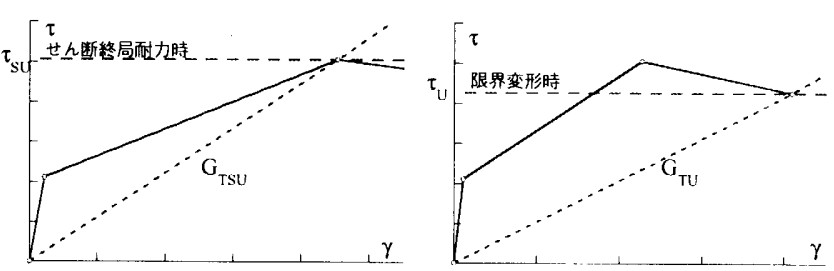

図-3 せん断破壞形部材のスケルトンカーブ

\section{2. 復元力特性評価手法の概要}

ここでは, 既報 ${ }^{5} に$ に述べたせん断成分の復元力特性.評価手法の概要 を示す. 本評価手法は, RC 造部材のせん断応力度 $(\tau)$-せん断変形角 $(\gamma)$ 関係の包絡線を求めるものである。このとき，部材スバン方问に 5 つの領域に分割し，各領域のて-関係の包絡線をトリリニアで表現し， それぞれを直列に結ぶことで部材のスケルトンカーブを求める。図 -2, 図-3に示す割線剛性（G $\mathrm{G}_{\mathrm{TSU}} ， \mathrm{G}_{\mathrm{TU}}$ ）または，曲げ降伏後の剛性の 低下を表現する接線剛性（ $\left.\mathrm{G}_{\mathrm{T} M \mathrm{MU}}\right)$ は，次式に基づいて算出する。特 に, せん断破壊先行型の場合，せ九断終局耐力時を第二折れ点とし， その後の勾配も定義することでトリリニアとする。このとき，せん 断終局耐力（第二折れ点）後の指问点を限界変形点と定義し，コン クリートが圧縮軟化域に入り压縮強度の $80 \%$ に低下し，せん断補強 筋が歪硬化により降伏強度の 1.1 倍まで上昇したと仮定して求める。

$$
\begin{aligned}
& G_{T}=1 /\left[1 /\left(K_{2} \cdot \cos ^{2} \theta \cdot \sin ^{2} \theta\right)+\tan ^{2} \theta / K_{X}+1 /\left(K_{Y} \cdot \tan ^{2} \theta\right)\right] \\
& \left(1 / K_{X}-1 / K_{Y}\right) \cdot \cos ^{4} \theta-2 \cdot\left(1 / K_{2}+1 / K_{X}\right) \cdot \cos ^{2} \theta+\left(1 / K_{2}+1 / K_{X}\right)=0
\end{aligned}
$$

ここで, $G_{T}$ : 求めようとする凬性 $\left(G_{T S U}, G_{T U}, G_{T M U}\right)$ を表す. $K_{2}$ は, 主圧縮方向の剛性を表し, コンクリートのヤング係数の 関数で表す， $K_{X}$ は，部材軸と直交する方向（X 軸方向）の剛性 を表し，せん断補強筋のヤング係数と鉄筋量，および中子筋の 有無などを因子として評価する。 $K_{Y}$ は，部材軸の方向（Y 軸方 向）の剛性を表し，主筋量や軸応力度を因子として評価する， $\theta$ は主圧縮方向の角度で, 部材軸方向とな角度で表す。各变数 は求める剛性 $\left(G_{T S U} ， G_{T U}, G_{T M U}\right)$ により異なり，それぞれの算 定方法は既報を参照されたい

\section{3. $R C$ 造柱部材の静的実験}

\section{1 試験体概要}

復元力特性評価法の評価精度を検証するために，曲げ降伏先行型 あるいは曲げ降伏前せん断破壊型の試験体を計画した。試験体一覧 を表-1に，材料特性を表-2 に示す。また，試験体配筋詳細(例)を図-4 に示す。試験体は，低層建物の中柱を想定し，実物の約 2/3 スケール

\begin{tabular}{|c|c|c|c|c|c|c|}
\hline & F10-N & F10-G & S6-N & S6-G & S13-N & S13-N-R \\
\hline 断面 & \multicolumn{5}{|c|}{$470 \times 470[\mathrm{~mm} \times \mathrm{mm}]$} & $700 \times 700$ \\
\hline 内法高さ & \multicolumn{5}{|c|}{$1410[\mathrm{~mm}]$} & 2100 \\
\hline 主筋 & \multicolumn{2}{|c|}{ 12-D22 } & \multicolumn{2}{|c|}{ 12-D25 } & \multicolumn{2}{|c|}{ 16-D32 } \\
\hline 㒼筋 & 目-D10@80 & 口-D10@40 & 目-D6@80 & $\square-D 6 @ 40$ & 目-D13@140 & 目-D13@100 \\
\hline
\end{tabular}

表-1 試験体一覧

\begin{tabular}{|c|c|c|}
\hline 碔験体 & $\sigma_{\beta}$ & Ec \\
\hline $\begin{array}{l}\text { S6, F10 } \\
\text { S13-N }\end{array}$ & 40.2 & 2.70 \\
\hline S13-N-R & 42.4 & 2.99 \\
\hline \multicolumn{3}{|c|}{$\begin{array}{l}\sigma_{\mathrm{B}} \text { : 圧缩强度, Ec:ヤング係数 }\left[\times 10^{4}\right] \\
\text { sy: 降伏强度. Es: ヤング係数 }\left[\times 10^{5}\right]\end{array}$} \\
\hline
\end{tabular}

(a) コンクリート

\begin{tabular}{c||c|c|c}
\hline 種類 & $\sigma_{y}$ & Es & 部位 \\
\hline D6 & 372 & 2.03 & S6 带筋 \\
\hline D10 & 377 & 1.95 & F10 带筋 \\
\hline D13 & 337 & 1.89 & S13 带筋 \\
\hline D22 & 347 & 1.95 & F10 主筋 \\
\hline D25 & 1006 & 1.94 & S6, S13-N 主筋 \\
\hline D32 & 1014 & 1.96 & S13-N-R 主筋 \\
\hline
\end{tabular}

$\begin{array}{ll}\text { (a) S6-N } & \text { (b) S6-G }\end{array}$

図-4 試験体配筋図例(上下対称なため上半分のみ示す)

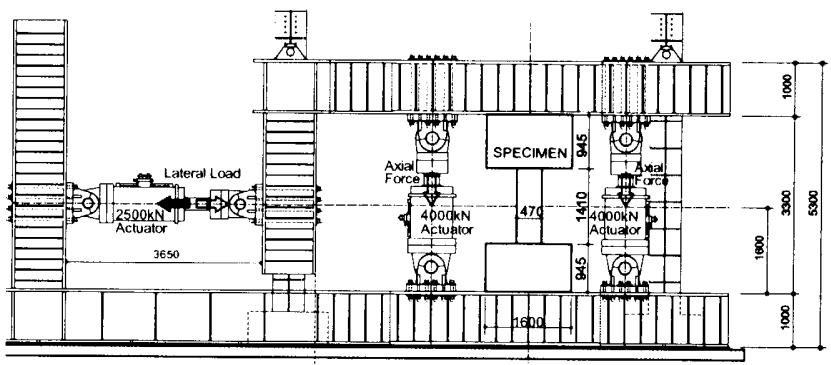

図-5 載荷装置図

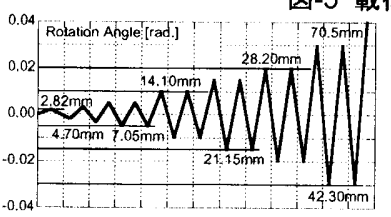

(a) F10 シリーズ試験体

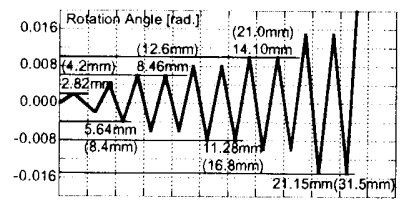

(b) S シリーズ試験体
図-6 載荷スケジュール

とした。既報で検証に用いた試験体を基準とし，曲げ降伏先行型で 中子筋の有無を变数としたF10シリーズ（F10-N, F10-G), せん断破 壊型で中子筋の有無を变数とした S6シリーズ（S6-N，S6-G）および せん断破壊型で寸法の違いを变数とした S13 シリーズ（S13-N, S13-N-R）の計 6 体とした。載荷装置図を図-5に，載荷スケジュール を図-6に示す．加力は，一定軸力下（軸力比 0.15）で，上下スタブ を平行に保ちながら水平力を与える正負交番繰り返し載荷とした。 本載荷装置は，2本の鉛直アクチュエーターの合力を一定とし，変 位を同一とするように制御することで，加力梁と基礎梁の平行を維 持している. 


\section{表-3 実験結果一覧}

\begin{tabular}{|c|c|c|c|c|c|c|}
\hline & F10-N & F10-G & S6-N & S6-G & $S 13-N$ & $S+3-N-R$ \\
\hline 曲げひびわれ & $120(0.51)$ & $119(0.51)$ & 129(0.55) & 199(0.85) & $80(0.34)$ & $626(1.19)$ \\
\hline 計算値 & \multicolumn{5}{|c|}{234} & 525 \\
\hline 曲げせん断ひびわれ & $480(1.03)$ & $481(1.03)$ & $400(0.85)$ & $349(0.75)$ & $401(0.86)$ & $825(0.78)$ \\
\hline 計算值 & \multicolumn{5}{|c|}{468} & 1052 \\
\hline せん断ひびわれ & $711(1.22)$ & $662(1.14)$ & $693(1.19)$ & $652(1.12)$ & $559(0.96)$ & $\begin{array}{c}1301 \\
(0.99)\end{array}$ \\
\hline 計算值 $\mathrm{Vmcr}$ & \multicolumn{5}{|c|}{581} & 1310 \\
\hline 1 段筋降伏 & $703(1.12)$ & $691(1.10)$ & - & - & - & - \\
\hline 計算値 Vmscr & \multicolumn{2}{|c|}{629} & & & & \\
\hline 2 段筋降伏 & $751(1.07)$ & $759(1.08)$ & - & - & - & - \\
\hline 計算値 Vscr & \multicolumn{2}{|c|}{700} & & & & \\
\hline 補強筋降伏 & - & - & $551(0.78)$ & $720(1.08)$ & $\begin{array}{c}733 \\
(0.86) \\
\end{array}$ & $\begin{array}{c}1813 \\
(0.98) \\
\end{array}$ \\
\hline 最大軵力 & $803(1.08)$ & $780(1.05)$ & 699(0.99) & $757(1.13)$ & $\begin{array}{r}1000 \\
(1.17)\end{array}$ & $\begin{array}{r}2295 \\
(1.23)\end{array}$ \\
\hline 計算値 (曲げ終局) & \multicolumn{2}{|c|}{743} & \multicolumn{2}{|c|}{1318} & 1333 & 4387 \\
\hline 計算値 $\left(V_{S U}\right.$ 既) & 1121 & 944 & 709 & 668 & 857 & 1856 \\
\hline 部算值 $\left(V_{S l}\right.$, thos) & \multicolumn{2}{|c|}{704} & 664 & 646 & 842 & 1751 \\
\hline
\end{tabular}

各強度計算值は以下の式(3)〜(5)による. ()内は実験値の計算値 に対する比。

Vmcr $=2 \cdot \mathrm{Mcr} / \mathrm{Lo}, \mathrm{Mcr}=\left(0.56 \sqrt{\sigma_{B}}+\sigma_{o}\right) \cdot \mathrm{Ze} \ldots \ldots \ldots \ldots \ldots \ldots$ (3)

Vmscr $=0.265 \cdot b \cdot D \cdot \sigma_{T}+M c r /(a-D / 2)$

$V s c r=b \cdot D \cdot \sqrt{\sigma_{T}^{2}+\sigma_{T} \cdot \sigma_{o}} / \kappa_{p}=b \cdot D \cdot \sqrt{\sigma_{T}^{2}+\sigma_{T} \cdot \sigma_{o}} / 1.5$

$V_{S U}$ 既は，既報 ${ }^{5)}$ によるせん断終局強度で，鞄性指針 ${ }^{8}$ によるせん 断終局強度式 $\left(V_{S U}\right.$ 勒) に以下の修正を加えたものである。 $v \sigma_{B}=1.71 \cdot(1+2 \eta) \cdot \sigma_{B}^{0.667}$ （NewRC 提案による軸力の効果） $\lambda=1-\frac{s}{2 \cdot j_{e}}-\frac{3 \cdot b_{s}}{8 \cdot j_{e}} \quad$ (有効断面積の影響 $)$

ここで, Mcr：曲げひびわれモーメント， $\sigma_{B}$ : コンクリート圧縮 強度, $\sigma_{o}$ : 軸応力度, $\sigma_{T}$ : コンクリート引張強度, $Z e$ : 等価断 面係数, $a$ : せん断スパン, $D$ : 断面せい, $b$ : 断面幅 その他の記号は文献 ${ }^{5)}$ による。

\section{2 実験結果}

実験結果一覧を表-3 に示す．F10 シリーズ試験体 2 体は，いずれ も部材角 $\mathrm{R}=1 / 100$ の加力サイクルにおいて主筋の引張降伏が確認さ れ,その後荷重はほほ一定となり, R=1/33の繰り返し載荷の後, F10-G では徐々に荷重が低下し，F10-N では $\mathrm{R}=1 / 20$ 以上の変形で急激に過 重が低下した、いずれも，曲げ降伏後のせん断破壊となった。最終 加力サイクルにおいて，主筋に沿った割裂ひびわれが顕著になって いることから，付着劣化を伴っていたと思われる（図-20ひびわれ図 参照). S シリーズ試験体はいずれも曲げ降伏以前にせん断破壊した。 $\mathrm{S} 6$ シリーズ試験体は， $\mathrm{R}=1 / 125$ あるいは $\mathrm{R}=1 / 167$ の加力サイクルで せん断補強筋の降伏が確認され，その後の荷重の上昇はみられず， $\mathrm{R}=1 / 50 \sim 1 / 33$ 程度の変形に至るまでに最大耐力の $80 \%$ まで耐力低下 した。一方 $\mathrm{S} 13$ シリーズは， $\mathrm{R}=1 / 125$ あるいは $1 / 167$ の加力サイクル でせん断補強筋が降伏した後も荷重の上昇がみられたが，その後の 大変形では荷重は大きく低下し，いずれもせん断破壊した（荷重一 変形関係は 5 章図-10を参照，その他の計測データも5 章，6 章にお いて計算および解析結果と比較しながら詳述する。)

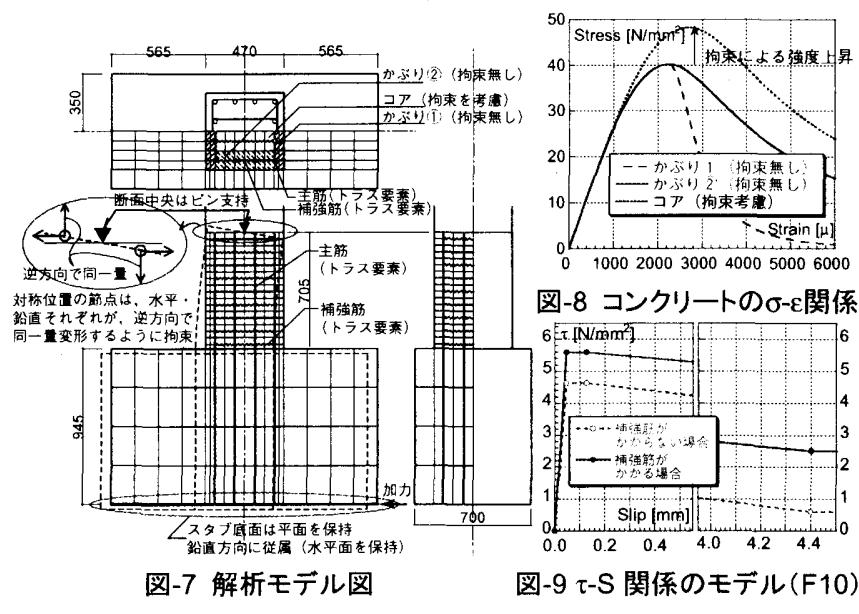

\section{FEM 解析概要}

FEM 解析は，大林組開発ソフト $\left\lceil\right.$ FINAL ${ }^{\text {9) }}$ を用いて行った。試験 体形状掞よび加力方法の対称性を考慮して, 試験体の断面幅方向中 央㧍よびスパン中央で切断した $1 / 4$ の部分をモデル化した。切断面の せい方向中央位置の節点を回転中心（ピン支持）とし，支持点に関 し対称位置にある切断面内の各節点は, 逆対称に変位するような境 界条件を与えた。一方, スタブについては, ス夕ブ底面が水平平面 を保持するような境界条件を与えた，要素分割図を図-7 に示す。コ ンクリートは六面体要素, 主筋および試験部分断面内のせん断補強 筋はトラス要素でモデル化した.コンクリートの応力度-歪度関係は， 修正 Ahmad 式 10)を用い，多軸応力下の破壊条件は，コアコンクリー トについてはOttosen の提案 ${ }^{11}$ に従い, 畑中らの係数 ${ }^{12)}$ 用いた。本 破壊基準では，拘束応力により最大強度が上昇する現象を再現でき る (図-8 参照)。一方，かぶりコンクリートについては，拘束による 強度上昇を考慮しないモデルとした，最大強度到達後は軟化域に入 り，応力低下による不釣合い力を解除する，また，鉄筋の応力度-歪 度関係はバイリニアとした。主筋のトラス要素とコンクリートの六 面体要素との間には，物理的な大きさを持たない接合要素を配置し， 主筋とコンクリート間の付着劣化によるすべりをモデル化した。こ のとき，藤井ら ${ }^{13)}$ の提案を元にした市ノ瀬 ${ }^{14)}$ の手法に基づいて付着 応力度-すべり関係を設定した. 付着応力度-すべり関係の例を図-9に 示す．解析は一方向漸增載荷解析とし，繰り返しによる耐力劣化な どは考慮せず，実験における最大耐力付近までを検討対象とした。

\section{5. 実験結果に対する解析結果および評価手法の対忘性の検討}

本章では, 提案手法による計算結果と FEM 解析結果 (以下, 解析 結果と呼ふ）の実験結果との対応性を検証する. 特に, 荷重-变形関 係のみでなく, 提案手法による剛性評価の過程で導かれる部材軸お よび部材軸直交方向の歪度㧍よび主応力角度について検証する。ま た，主筋歪度について解析結果と実験結果の比較も行う。

\section{1 荷重-変形関係}

各試験体のせん断応力度-部材角関係を，塞験結果と計算結果およ び解析結果とを比較して図-10に示す。また，せん断応力度-せん断 変形角関係を図-11に示す。このとき, 全体変形から, 測定值より求 めた曲げ変形 (図-13 参照) を除いたものをせん断変形と定義した。 計算における曲げ変形成分は三折れ線により評価するため, F10 シリ 

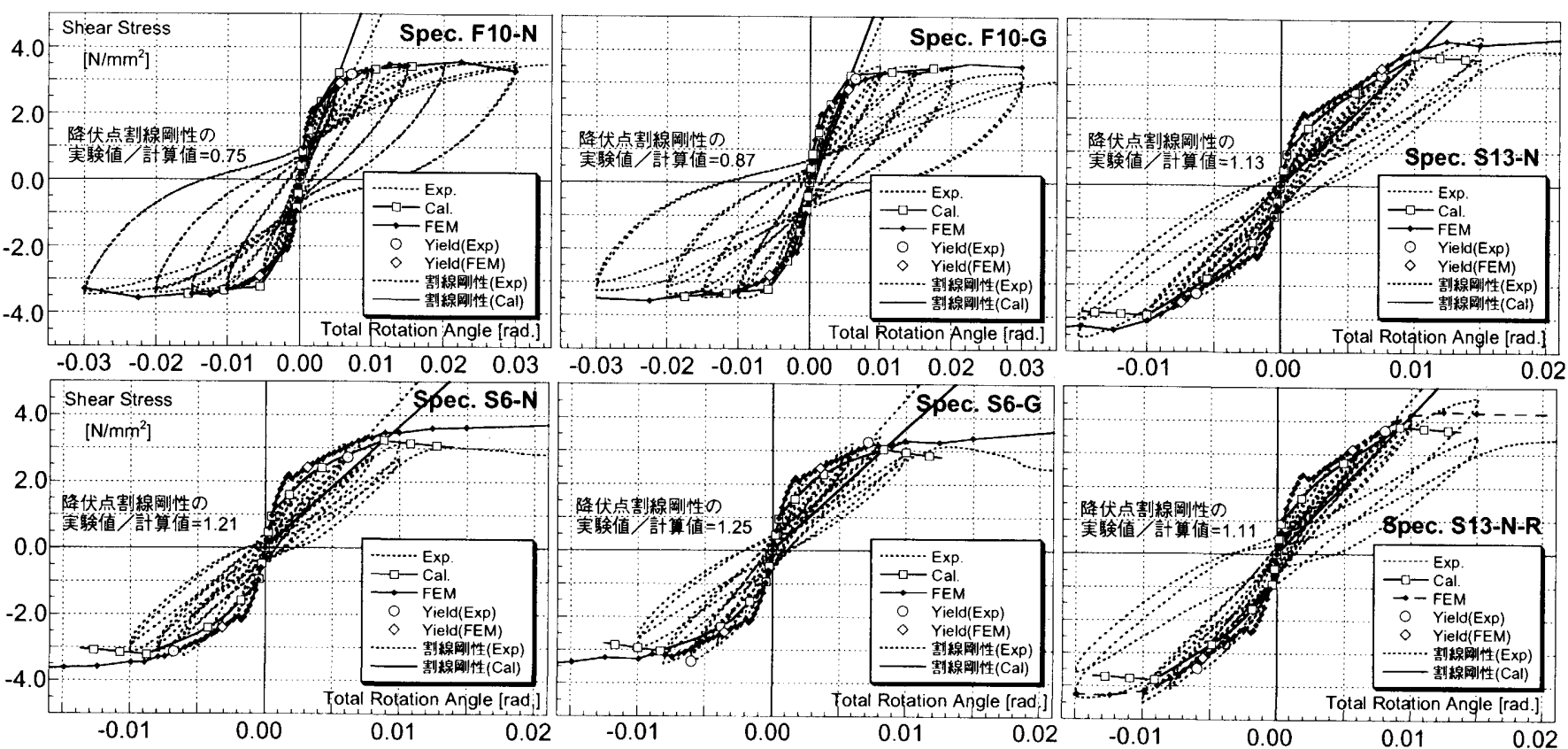

図-10 女ん断応力度 $(\tau)$-部材角 $(R)$ 関係
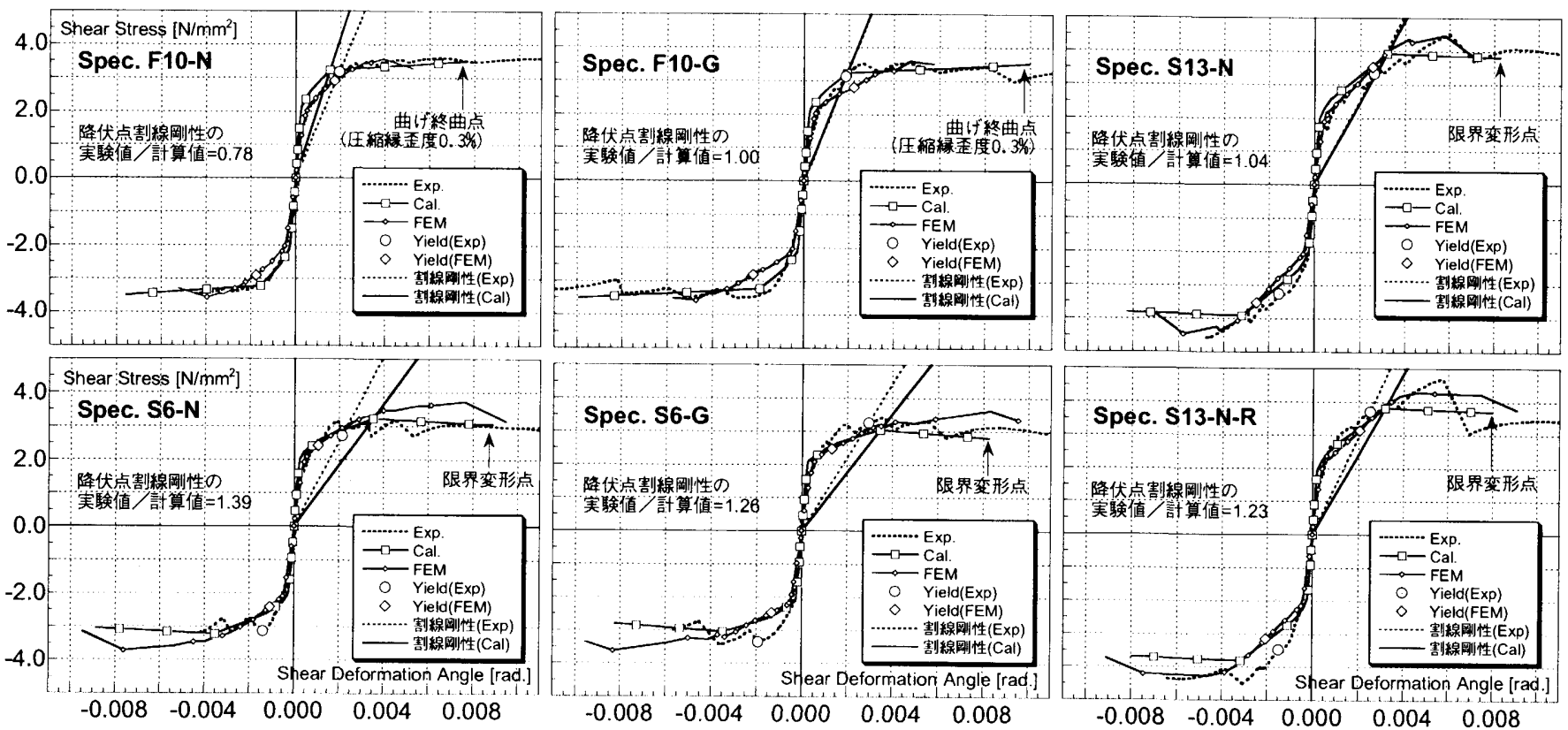

图-11 世九断応力度 $(\tau)$-世ん断変形角 $(\gamma)$ 関係

ーズでは二段筋の降伏時を降伏点とし，S シリーズでは，曲げ降伏に 至る前に破壊していることから，一段筋の降伏時により降伏点㴊性 を算出した。解析結果および計算結果は, 破壊性状により若干傾向 の違いは見られるものの, 概ね実験結果と対応しているといえる。 実験值の計算值に対する比は，せん断耐力式に靸性指針式を用いた 場合平均值 1.14 , 変動係数 $8.9 \%$ となるのに対し，せん断耐力式に提 案式を用いた場合, 平均值 1.11 , 変動係数 $8.0 \%$ となり, 靸性指針式 と同程度以上の評価精度であった（表-3）。一方，特に実験において せん断補強筋または主筋の降伏が確認された点の割線剛性と, 復元 力特性評価法で算出される第二折れ点時割線剛性とを比較すると, 実験値の計算值に対する比は, 平均值 1.05, 变動係数 $19.0 \%$ となり(女 ん断変形成分の場合それぞれ 1.11，19.6\%)，概ね対応している。ま た，破壊モード別に見ると，せん断破壊型の S6 シリーズでは過小評
価する傾向にあり，曲げ降伏先行型の F10 シリーズでは過大評価す る傾向があり，この傾向は全体変形成分，せん断変形成分いずれに も見られる。これ以降，せん断変形成分に着目して議論を進める。

\section{2 歪度分布}

各試験体の主筋歪度分布を実験結果と解析結果を比較して図-12 に示す. 図は, F10 シリーズ試験体では部材角 $\mathrm{R}=1 / 100$ 時, $\mathrm{S}$ シリー ズ試験体では $\mathrm{R}=1 / 125$ 時を代表して示した. F10シリーズ試験体では, 解析結果は実験結果に対し, 圧縮歪度を大きく評価する傾向にある ものの，降伏後の引張歪度を概水評価できている，また，せん断破 壊型とともに，二段筋の歪度分布状況や，中子筋の有無に上り中子 筋の掛からない鉄筋の歪度が掛かる鉄筋に比べて小さくなる状況な どを解析により再現できているといえる。 

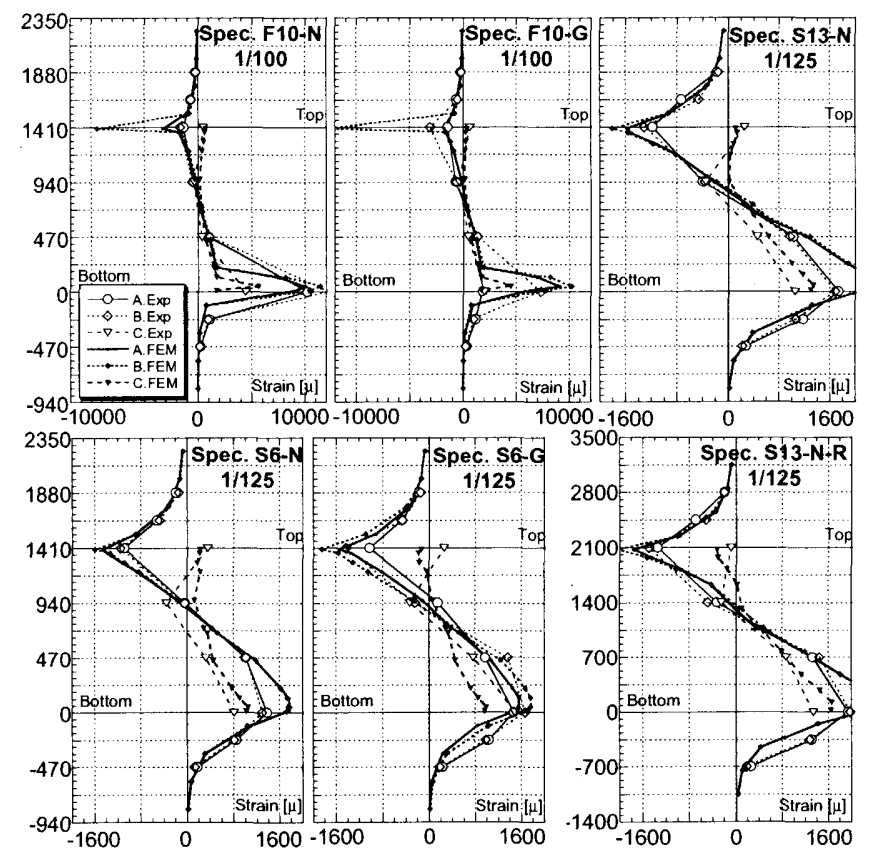

A,B,Cはそれぞれ鉄筋位置を表す。位置は図-4 参照。

図-12 主筋ひずみ度分布

\section{3 復元力特性評価法の計算仮定の検証}

本節では，提案手法の計算仮定に関する検証を行う。すなわち， 割線剛性評価において構成するX 軸方向（加力面内の部材軸と直交 する方向）および，Y 軸方向（部材軸方向）の歪度の評価結果を， 解析により得られた結果を参照しながら実験結果と比較する。また， 主応力角度の計算仮定について, 解析結果を参照しながら, 実験結 果と比較検証する。

$X$ および $Y$ 軸方向の歪度 $\left(\varepsilon_{X}, \varepsilon_{Y}\right)$ は剛性導出の過程から, 以下 のように表現できる。

$$
\left\{\begin{array}{l}
\varepsilon_{X} \\
\varepsilon_{Y}
\end{array}\right\}=G_{T} \cdot\left\{\begin{array}{c}
\tan \theta / K_{X} \\
1 / K_{Y} \cdot \tan \theta
\end{array}\right\} \cdot \gamma_{X Y}
$$$$
\tau_{X Y}=G_{T} \cdot \gamma_{X Y}
$$

ここで, $\tau_{X Y}$ ：せん断応力度, $\gamma_{X Y}$ : せん断変形角, $K x, K y, G_{T}$, $\theta$ は，各折れ点に対応する变数を用いる。

\section{(1) X 軸方向歪度}

実験では，柱脚部付近，スパン中央付近抒よび両者の中間付近に おいて, 断面せい方向に直径 $6 \mathrm{~mm}$ のパイプを貫通して埋入して㧍き， せい方向の膨らみ変位を測定した ${ }^{15}$. また, 約 $0.5 \mathrm{D}$ (D:柱断面せい) 間隔毎に測定した軸方向変形から，曲率を算出する一方で，同一高 さ位置の水平変位を測定した。これらの結果から, 領域毎の全体変 形拉よび曲げ変形を算出し，両者の差をせん断変形とした（図-13）。

F10 およびS6 シリーズのスパン中央付近における膨らみ変位測定 結果から X 軸方向歪度を算出し, せん断応力度 $\mathrm{X}$ 軸方向歪度関係と して図-14に示す。計算結果および解析結果もあわせて示す。実験で は，小さな歪度で推移した後，急激な歪度の増加が起きており，こ れは，測定位置にひびわれが生じたことによると考えられる。計算 結果は，このような歪の進展状況とほほ対応している，特に，ひび われ後の歪度は，計算結果の第二折れ点（曲げ降伏点あるいはせん

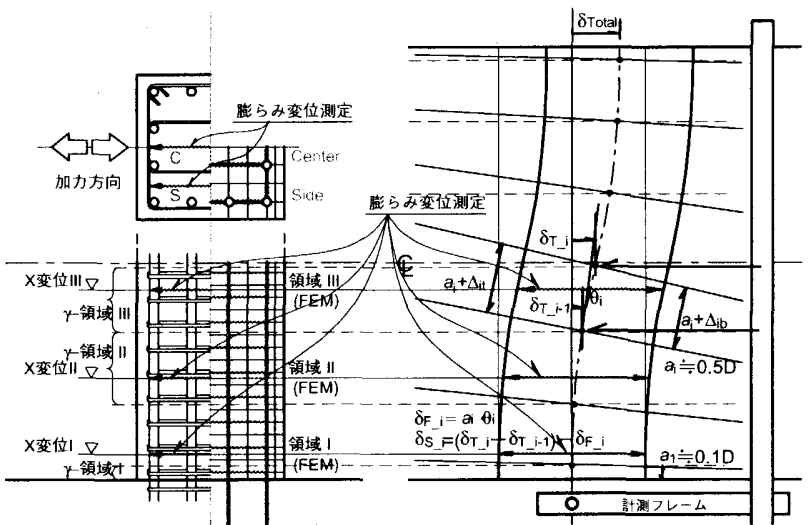

図-13 変位計測位置と解析要素位置

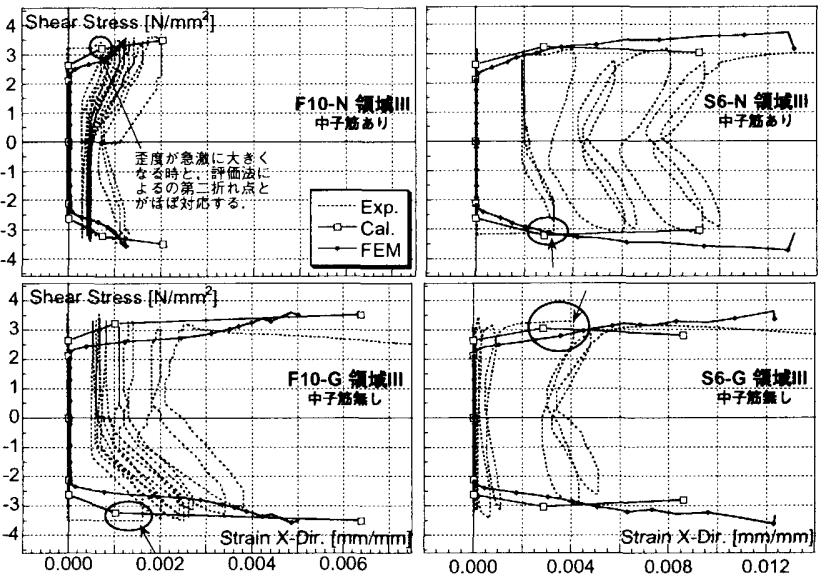

図-14 中子筋の有無とせん断応力度-X軸方向歪度関係
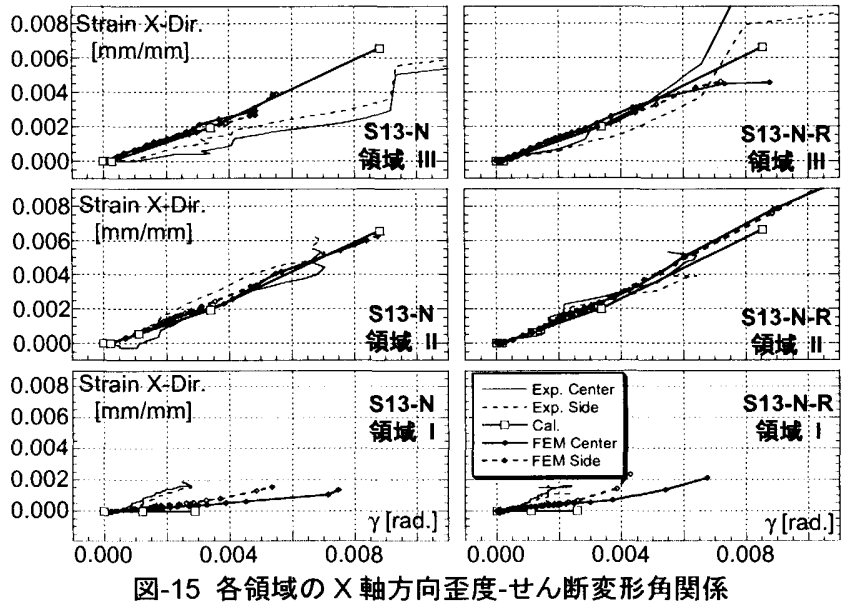

断終局耐力点）時の歪度と対応している（図中矢印および丸で囲ん で示す)。このことは，ひびわれ発生後の割線剛性を求めるという本 評価手法との対応性を示しているといえる.また, F10 シリーズでは， 中子筋が無い場合に歪度が大きくなるのに対し，中子筋があること で歪度の增加が小さく押さえられて扔り，計算結果でも同様の傾向 が見られ，よく対応している。この傾向は，S6 シリーズではあまり 顕著に見られず，曲げ降伏先行型部材において特に, 中子筋の有無 がせん断性状に大きな影響を与えることを示唆しているといえる.

次に, S13 シリーズの領域毎の X 軸方向歪度-せん断変形角関係を 包絡線で図-15に示す，計算・解析結果ともに，契験結果とよく対応 している. 特に領域 I（柱頭柱脚付近）で歪度が小さく, X 軸方向剛 性を無限大とする計算仮定の妥当性を示すものといえる．また，部 材寸法の違いが歪度に与える影響は見られない。 


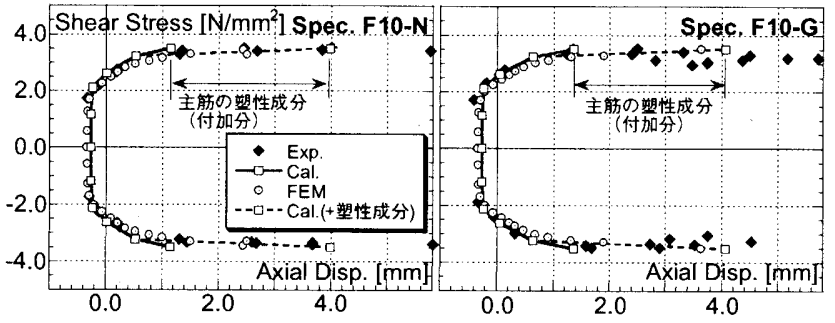

図-16 Fシリーズ試験体のせん断応力度-Y 軸方向変位関係
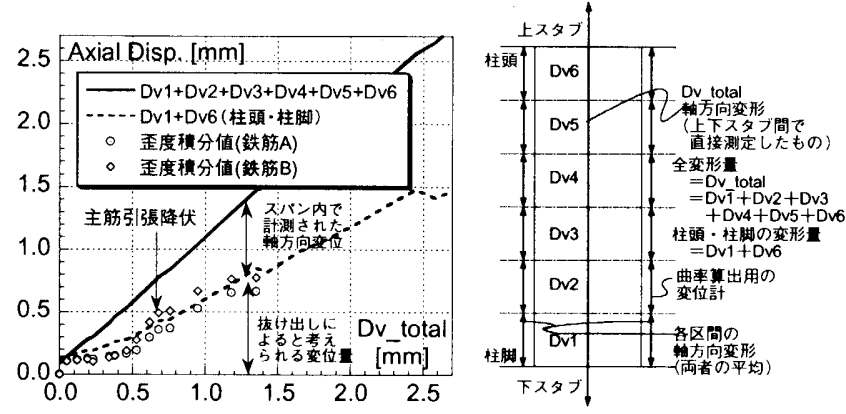

図-17 䄳度積分値と計測値の比較

\section{(2) Y 軸方向歪度}

$\mathrm{Y}$ 軸方向歪度計算值を領域每に積分して和をとり, 部材軸方问変 形に換算したものを，実験結果と比較して図-16に示す。実験值は， 上下スタブに固定したボルト間距離の測定値である。図は, F10シリ ーズについて，せん断応力度-Y 軸方向変位の関係を示した。解析結 果もあわせて示す。ここで, 計算では, 一定軸力載荷直後の軸方向 変形 (縮み量) を,コンクリートと鉄筋のヤング係数比を考虑した 等価断面積から算出した。実験掞よび解析では, 曲げ降伏した後（せ ん断応力度がほほ（定となってから), 軸方向変位が伸びる傾向があ り計算ではこの傾向が追跡できていない(軸方向変位 $1 \mathrm{~mm}$ 程度まで). これは, 主筋の降伏後の塑性化や抜出しにより部材軸方向変位が大 きくなる現象が，提案手法では評価できていないことによると考え られる。ここで, 試験体 F10-N の場合の軸方向変位測定値を図-17に 示す．図には，軸方向変形測定值（Dv_total）と，柱脚および柱頭で 測定した軸方向変形（Dv1+Dv6）, 同じく曲率算出用に計測した左

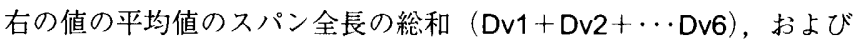
主筋歪度分布の積分値を示す。主筋歪度分布の積分では, 引張側主 筋のスタブ内 $0.5 \mathrm{D}$ 区間で計測した歪度を用い，圧縮側の伸縮をゼロ と仮定して, 積分值の $1 / 2$ を柱頭または柱脚の軸方向変位とした. 図 より，直接計測した軸方向変位（Dv_total）と曲率算出用の変位計の 值から換算した変位（Dv1+Dv2+Dv6）はほほ同等であること， 柱頭柱脚に生じる軸方向変位（Dv1+Dv6）は，主筋歪度の積分値と 同等であり, 軸方向変位の 6 割程度を占めていることがわかる。こ のことから, 主筋引張降伏後の部材軸方向変位は, 柱頭柱脚に集中 して扮り，その值は，主筋の抜け出しによるものであると考えられ る。そこで, 図-16には, 主筋の歪度 (断面解析により得られた圧縮 縁歪度 $0.3 \%$ 時の引張鉄筋歪度）を，ヒンジ長さ（1.0D と仮定した） において積分した值を足したものも示した．図-17と同様に，圧縮側 の伸縮をゼロと仮定し，引張側の伸び量の $1 / 2$ を軸方向変位とし，柱 頭柱脚に等しい軸方向変位が生じると仮定した。この結果，計算結 果は $4 \mathrm{~mm}$ 程度となる。

一方, $\mathrm{S}$ シリーズ試験体について, $\mathrm{Y}$ 軸方向変位-せん断変形角の

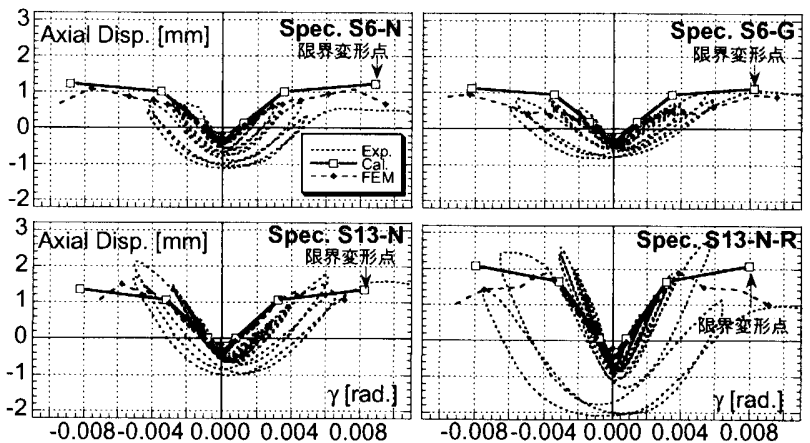

図-18 Sシリーズ試験体の Y 軸方向変位-せん断変形角関係

関係を図-18に示す。この場合，せん断終局耐力時までの軸方向変位 の増加傾向, およびその後の変動傾向が, 計算および解析結果とも, 春験結果とよく対応している，特に，実験結果では，耐力低下の開 始とともに, 軸方向変位が伸びから縮みに転じており, 計算結果の 限界変形点付近がこれらの事象と対応している。

以上のことから，曲げ降伏以前の部材軸方向変位は，本提案手法 により得られる軸方向歪度の積分值として概ね評価できるといえる。 一方，降伏後の軸方向変位については，本提案手法により得られる 值では不十分であり，主筋の塑性化などの影響を考慮する必要があ ることが示唆された。

\section{（3）主圧縮方向角度}

主圧縮方向角度（部材軸から反時計回りを正）の評価精度を，春 験結果および解析結果と比較する。主圧縮方向角度は実験では得ら れないため，スケッチしたひびわれ状況と比較することとした．解 析結果は, 各要素のうち, 最外縁部の要素の主応力角度により代表 して示すこととした，また，計算值は，5分割した領域每に得られ るため，各領域の高さ方向中央位置に図示することとした，計算お よび解析結果は, 対称性から部材上部半分のみ示した。各試験体の 第二折れ点（せん断終局耐力点または曲げ降伏点）を図-19に，第二 折れ点後の指向点 (限界変形点または曲げ終局点)を図-20に示した.

主厤縮方向角度は，計算においては，領域 I において約 40～50 となり，それ以外の領域では約 $25 \sim 35^{\circ}$ 程度となり，中子筋の有無 や補強筋量, 破壊モードなどの影響は顕著には見られない。図示し た結果では, 領域 I（柱頭柱脚近傍）の主圧縮方向角度が大きい（部 材軸に対する角度が大きい）傾向があり，解析招よび計算結果でも 同様の傾向が見られることがわかる．また，せん断終局耐力時は， 実験・解析ともに，スパン中央付近の主圧縮方向角度が比較的小さ く, 計算とやや対応しないが, 限界変形時ではよく対応しているこ とがわかる. 以上のことから, 評価手法において柱頭柱脚とその他 の部分とを領域分割することの妥当性を示しているといえる.

\section{6. せん断ひびわれ幅算定法}

ひびわれ幅は，引張主歪度とひびわれ間隔（図-21参照）の積とし て算出する ${ }^{16), 17}$ ，ひびわれ幅の算定は，領域にについて代表して求 める. 各折れ点における最大ひびわれ幅 $\left({ }_{\text {max }} W_{s}\right)$ は次式による。 せん断 応力度-せん断変形角関係とせん断ひびわれ幅の関係を図-22 に示す.

$$
\begin{aligned}
& { }_{\min } W_{s}=L_{\text {min }} \cdot \varepsilon_{1} . \\
& { }_{\max } W_{s}=2{ }_{\text {min }} W_{s} .
\end{aligned}
$$




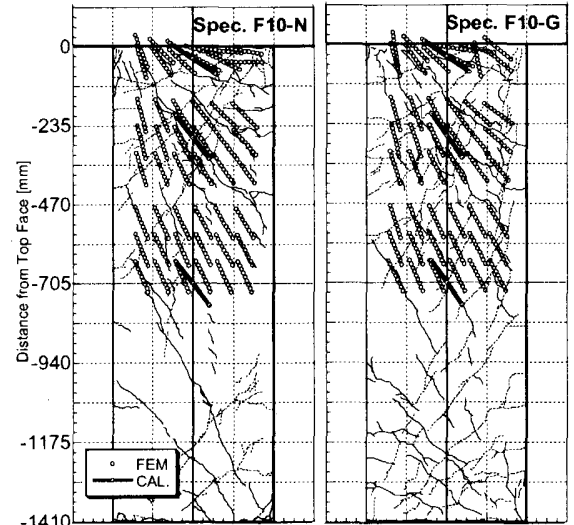

(a) 曲げ降伏後 (部材角 $R=1 / 67$ )

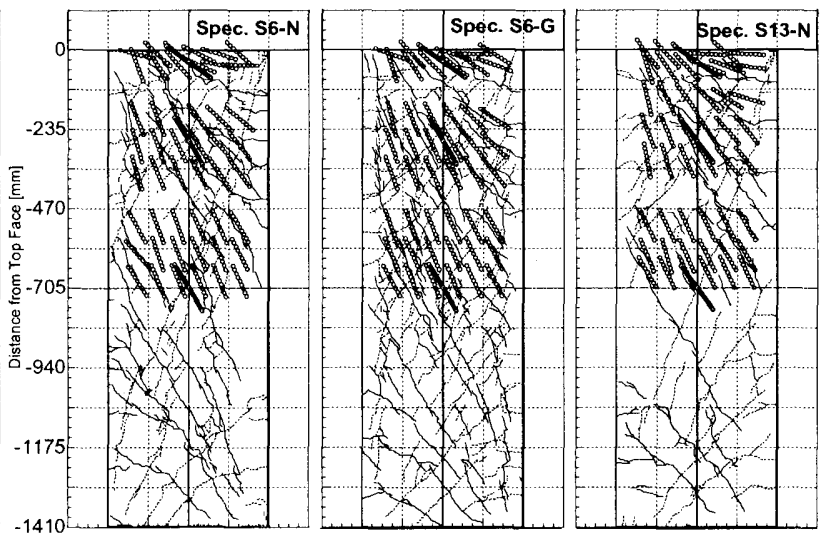

(b) せん断終局酎力点 (部材角 $\mathrm{R}=1 / 100$ )

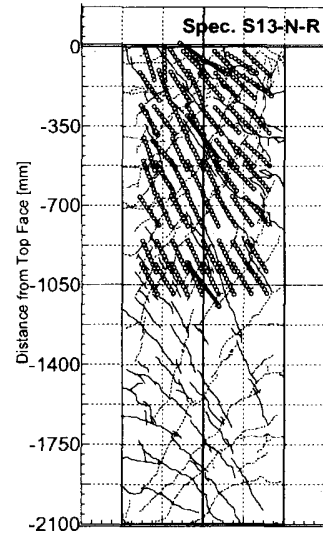

.

伏またはせん断終局耐力時)
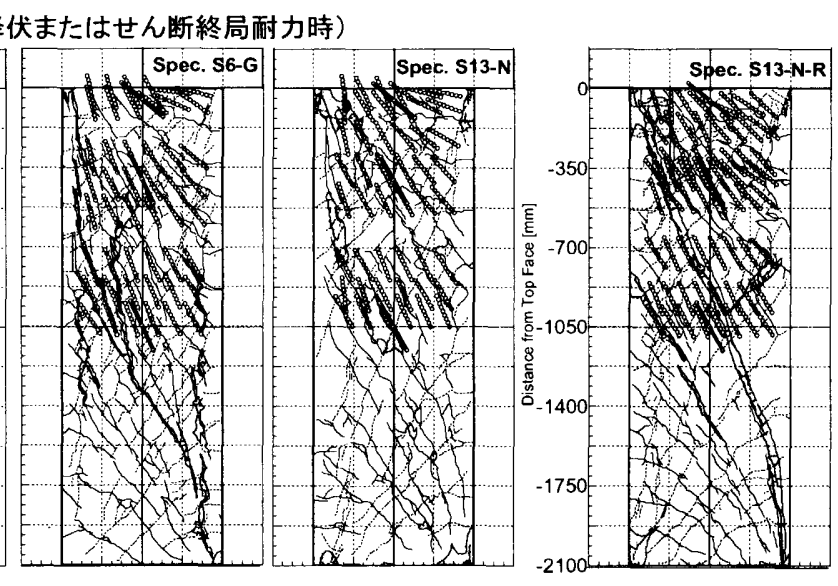

(b) 限界変形点 (最終破壊状況)

図-20 主応力角度分布 (最終破壊時)
$L_{\min }=2 \cdot \sigma_{T} \cdot b_{e w} \cdot t_{c} /\left(\tau_{X} \cdot \phi_{X}+\tau_{Y} \cdot \phi_{Y}\right)$

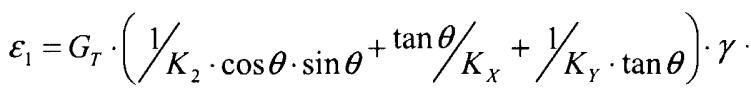

$b_{e w}=S_{X} \cdot \sin \theta+S_{Y} \cdot \cos \theta$

$\tau_{X}=0.7 \cdot\left(1+\frac{\sigma_{O}}{\sigma_{B}}\right) \cdot \sigma_{B}^{0.667}, \quad \tau_{Y}=0.7 \cdot \sigma_{B}^{0.667}$

$G_{T}$ および日は，各折れ点に対応する值を用いる。

$t_{c}$ : 主筋芯から側面までの距離 $\times 2, S_{X}$ : 主筋間隔 $[\mathrm{mm}], S_{Y}$ : せ 乙断補強筋間隔 $[\mathrm{mm}], \phi_{X}$ : せん断補強笳の周長 $[\mathrm{mm}], \phi_{Y}$ : 主筋 の周長 $[\mathrm{mm}], \sigma_{B}$ : コンクリート圧縮強度 $\left[\mathrm{N} / \mathrm{mm}^{2}\right], \sigma_{O}$ : 軸方向応

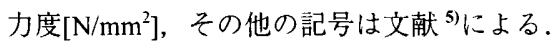

曲げ終局時点(MU)に対しては(10)，(13)に変えて次式を用いる。 $\min _{s} W_{s}=L_{\min } \cdot \Delta \varepsilon_{1}+{ }_{\min } W_{s . M Y}, \quad \max _{s} W_{s}=2 \cdot{ }_{\min } W_{s}$

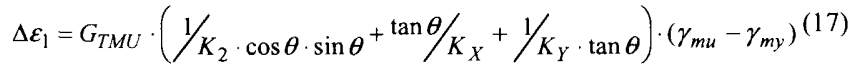

${ }_{\text {min }} W_{\text {s.MY }}$ は曲げ降伏点における最小ひびわれ幅で，せん断終局耐力 点におけるひびわれ幅から線形補完して算出する。

部材角ひびわれ幅関係の計算値と実験值を比較して S シリーズ試 験体の場合を図-23に，F10 シリーズ試験体の場合を図-24に示す.

ひびわれ幅の計測は，クリップ型変位計または二軸型亀裂変位計 を用いた計測（図中 Measured）と，目視でクラックスケールを用い た観測（図中 Observed）によった，変位計による計測では，正方向 加力時にひびわれ発生を確認したあと，ひびわれ方向とほぼ直交す る方向の変位を測定できるように変位計を設置し, 負方向加力終了
後, 荷重がゼロとなった時点を起点として測定を開始した，目視に よる計測は, 各加力サイクルピーク時に測定した。図は, 正加力時 サイクルピーク時の值のみ示した。 せん断破壊型で中子筋の有無を 変数とした場合, 同一変形時に, S6-G に比べ S6-N の方がひびわれ 幅が大きくなる傾向がある，これは，同一補強筋量として中子筋が ある場合 (S6-N)，せん断補強筋間隔が大きくなるため，ひびわれ幅 が大きくなると考えられる．この傾向は計算でも評価できている. また，S13-N と S13-N-R では，試験体寸法による有意な差はなく， どちらも計算により実験結果を概ね評価できている．本実験では， 鉄筋間隔が大きく異なるため, 寸法の違いによる影響を表す結果で はないと考えられる.

F10 シリーズ試験体では, 中子筋の有無により，ひびわれ幅の大き さに有意差は見られないもののせん断変形量が異なっており,この 傾向は計算でも評価できている，すなわち，中子筋があることによ りせん断変形量は小さくなるものの, 降伏時および曲げ終局時のひ びわれ幅はそれぞれ $0.2 \mathrm{~mm}, 1.0 \mathrm{~mm}$ 程度となっている．横軸をせん 断変形角とすると（図-24(b))，この傾向がより顕著となる.

ひびわれ幅の算定にあたっては, 試験体変数による違いを概ね評 価できているが, 特に S6シリーズで, 過小評価する傾向がある。こ れは，ひびわれ間隔の算定において仮定している付着応力度の算定 を過大評価しているためと考えられる．特に，細径の鉄筋（D6）を 用いた場合には, 式(15)で得られる付着応力度を発揮していないと考 えられる。そのため, 付着応力度については, より実状に近い算定 法を考案することが，ひびわれ幅評価精度向上につながるといえる。 

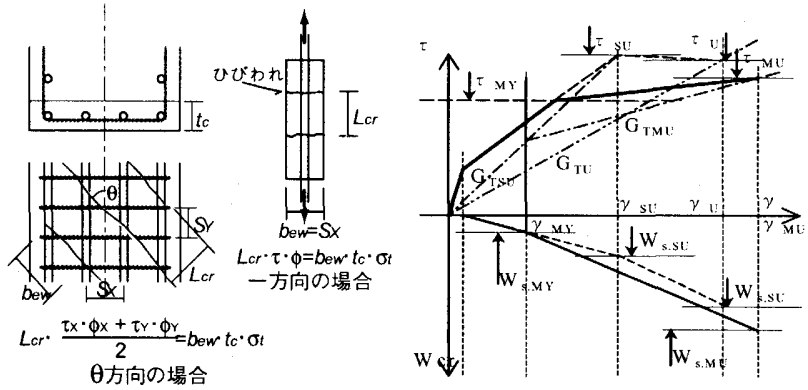

図-21 ひびわれ間隔 $\left(\mathrm{L}_{\mathrm{cr}}\right)$ の算定

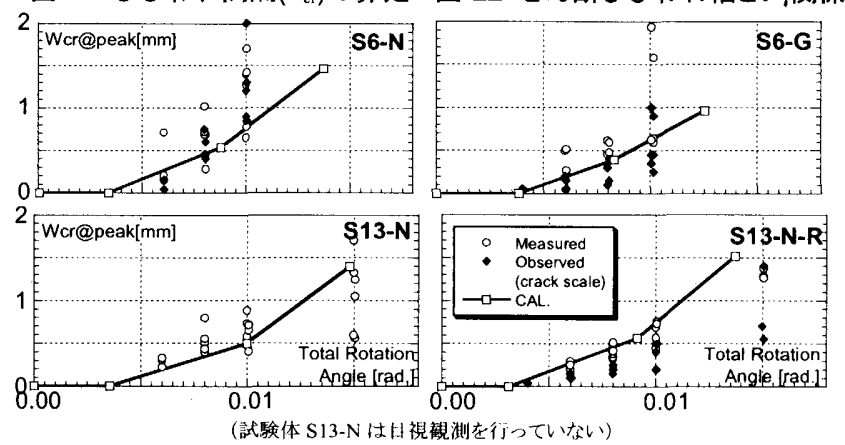

図-23 せん断ひびわれ幅-部材角関係(S シリーズ試験体)
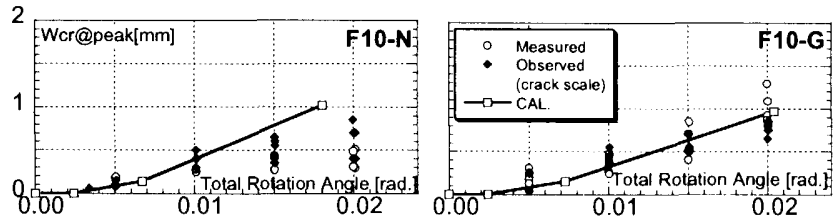

(a) せん断ひびわれ幅－部材角関係
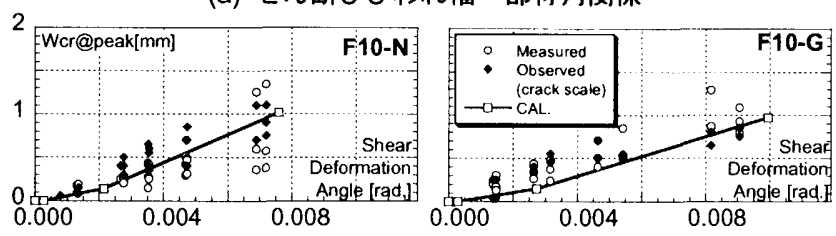

(b) せん断ひびわれ幅一せん断変形角関係

図-24 せん断ひびわれ幅(Fシリーズ試験体)

\section{7. まとめ}

鉄筋コンクリート造部材のせん断変形性状の把握およびひびわれ 幅デー夕の収集を目的として柱部材の静的実験を行い，既報に述べ た復元力特性評価手法と FEM 解析それぞれによる復元力特性の評価 精度を検詿した。その結果，以下の知見が得られた。

（1）部材軸直交方向歪度：曲げ降伏先行型の試験体では, 中子筋の 有無により，部材軸直交方向の歪度に大きな差が生じることが確認 され，結果として，中子筋があることによりせん断変形成分が小さ く押さえられることがわかった。この傾向は，提案手法によって評 価可能であるとともに, FEM 解析結果においても同様に確認された.

(2) 部材軸方向歪度: せん断破壊型の場合, 提案手法により算出さ れる軸方向歪度は，実験結果とよく対応しており，せん断剛性に寄 与する成分の一つである部材軸方向剛性が，部材の伸び变位を生じ させていることが推察された。一方，曲げ降伏先行型の場合，主筋 の降伏までは精度よく評価できるものの, 降伏後の軸方向変形成分 には，主筋の塑性化と抜出しに起因するものが支配的になる場合が あり，これらの影響を考慮する必要があることが推察された。

(3) 主圧縮方向角度: 実験により観察されたひびわれ方向と, 主圧 縮方向角度の計算結果拉よびFEM 解析の結果得られた主応力角度そ
れぞれの対応を比較した結果，計算仮定とした領域分割が概ね妥当 であることがわかった。ただし，既報および本論文で検証した範囲 外（せん断スパン比 2 以上あるいは 1 未満）については，分割長さ の妥当性の検証が必要であると考えている.

（4）せん断ひびわれ幅：剛性評価法に基づき，せん断ひびわれ幅の 評価法を提案し，実験結果と比較した。その結果，破壊モード，中 子筋の有無などにより異なる,ひびわれ幅の伸展状況を, 概ね評価 できていることがわかった。

本論文では, 復元力特性およびひびわれ幅の評価として, 包絡線 を基本としており，繰り返しによる耐力低下が生じるような履歴特 性については言及していない。 また, ひびわれ幅については, 最大 応答值に相当する変位ピーク時の値を対象としている。そのため, 実際の地震時の挙動を評価するためには，履歴特性掞よび残留ひび われ幅の評価手法も必要であり，今後の検討課題である。

\section{謝辞}

本研究を進めるにあたり，東京大学 塩原等助教授より懇切丁寧な ご指導をいただきました。ここに記して感謝の意を表します。また， 本論文執筆にあたり貴重な助言をいたたいた(株)大林組 長沼一洋・ 津田和明 両博士に謝意を表します。

\section{参考文献}

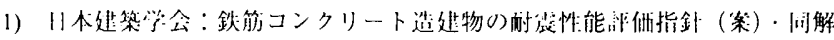
说, 2004

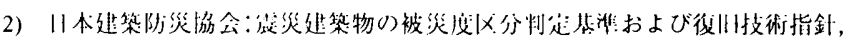
2001

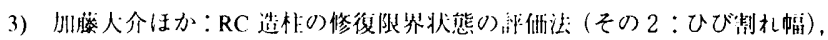

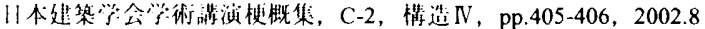

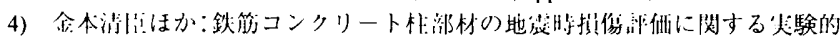

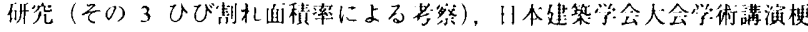
概集，C-2，構造 $N$, pp. $407-408,2002.8$

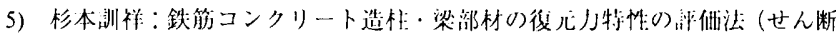

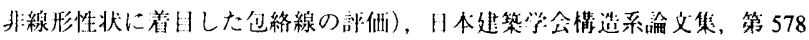
ij, pp.123-130, 2004.4

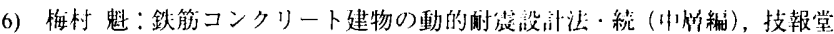
计版, 1982

7）梅村 恒，境有紀，南忠夫，壁谷澤㚘海：繰り这し战苮による的力低下が 地震応答に与える影響（その1）復元力特性モデルの開発，日本建築学会 大会学術講演梗概集, C-2, 構造 $N$, pp.27-28, 1998.9

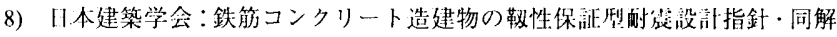
説, 1999

9) 長沼一洋, 米澤健次ほか：RC 構造部材の三次元絽返L FEM 解析の精度 们上その 3 非直交ひび割机モデルの改良と付着すべりモデルの導入，日 本建築学会大会学術講演梗概集, C-2, 構造 N, pp.427-428, 2003.9

10）長沼一洋：三軸圧縮下のコンクリートの応力 ひずみ関係，日本建築学会 構造系論文集，第 474 号, pp.163-170, 1995.8

11) Ottosen, N. S. : A Failure Criterion for Concrete, Journal of the Engineering Mechanics Division, ASCE, Vol. 103, No. EM4, pp.527 535, Aug. 1977

12）烟中重光, 服部宏已ほか：低側压 3 軸压縮下の高強度コンクリートの塑性 变形挙動,コンクリート工学年次論文集, 12-2, pp.719 724, 1990

13）後藤定己, 森田司郎, 藤井栄ほか：割り裂き付着強度モードに与える横補 強筋の影響，日本建築学会近畿支部研究報告，pp.197-200，1981.6

14）市八瀬䰻勝：鉄筋コンクリート短柱における付着破壊のメカニズム，日本 建築学会論文報告集, No.333, pp.73-83，1983.11

15) 岡野忠司], 今井正洋ほか：繰り返し載修を受ける $\mathrm{RC}$ 部材の3 次元的せん 断破壤，コンクリート工学年次論文集，Vol.22，№.3，pp.571-576，2000

16）津田和明ほか:鉄筋コンクリート造連層酎震壁の曲げ及びせん断ひびわれ 幅の算定法, 日本建築学会構造系論文集, 第 575 号, pp.97-104, 2004.1

17）安達洋ほか:鉄筋コンクリート造耐震壁のせん断ひびわれ発生機構に関す る研究，第 3 回コンクリート工学年次論文報告集, pp.469-472, 1981

（2004年 8 月 3 日原稿受理， 2005 年 2 月 22 日採用決筀） 